\title{
Perspectives
}

\section{Tools of Recursion, Intermental Zones of Proximal Development, and Critical Collaborative Autonomy}

\author{
Tim Murphey \\ Nanzan University
}

Exploratory teaching (Altwright, 1991) was conducted in a Japanese university EFL course in which students were asked to study themselves as learners in participatory action research (Auerbach, 1994). Weekly student commentary shows how reflection-in-action, reflection-on-action (Schön, 1987), and reflection literacy (Hasan, 1996) were encouraged by the recursive microdiscursive tools of shadowing and summarizing while recording conversations, and by the recursive reflective tools of action-logging and newsletters. Highlighting student voices through newsletters seemed to enrich the participants' sense of a common intermental space in which to negotiate and scaffold meaning. These tools of recursion helped students manifest what their minds were modeling, making comprehensible what they were thinking to themselves and to others, and create overlapping intermental zones of proximal development (Vygotsky, 1934). Comments from student action logs are used to support the idea that intermental interaction can lead toward critical collaborative autonomy (Murphey \& Jacobs, 2000).

本稿では、日本の大学の第 2 言語習得研究のクラスに出いて試行された探究 的な授業研究について発表する。生徒には、自ら、言語学習の対象者としてア クションリサーチに参加し、協力するよう依頼した。シャドーイングと要約の 練習をテープに録音させながら每週繰返して行い、授業日誌(action log)を書か せ、ニュース゚レターでフィードバックをした結果、生徒が自ら授業を振り返 り、自身の言語習得過程を熟考するようになっていくことが、生徒の感想から 明らかになつた。特に、ニューズレターを用い、生徒の声をクラスの仲間と共 有させることは、生徒間の内的なインタラクションを促進し、相互理解を深め ることに役立つようである。また、こうした学習過程を繰り返すことは、生徒 自身がお互いに考えていることをはつきりさせ、ウィゴッキーの提唱するZPDS (zones of proximal development)の形成に寄与することが分かった。つまり、 生徒間の内的なインタラクションが、批判的、協力的、自主的な学習集団の形 成につながるということである 
I alone cannot step out from the world I constructed. If I study alone, I may be confined to this finite world forever. But, by taking cooperation into learning, I can expand and enrich this world and its expanding is infinite. (From a student's action log, included in class newsletter \#7)

The quality of the conversation is not necessarily decided by English proficiency, but by the attitude of trying to understand each other well. (From a student's action log, included in class newsletter \#8)

T

read these comments in Rika and Miki's (pseudonyms) action logs toward the end of the first semester and put them into the newsletter for the next class. I wanted everybody to read those lines, to think about them, and talk about them. I also wanted to think about them myself. "What we want for one student is what we should want for ourselves" (Leibowitz, 2000, p. 77).

In my weekly university SLA class held in a language laboratory, the students audio-recorded conversations and then listened to them and reflected on their performances. They had also grappled with the concept of constructivism, the idea that knowledge is not simply transmitted to learners; rather, learners construct their own individualized understanding of concepts based on their previous experience, abilities, learning styles, the context, and probably much more. The students became aware that new learning often first occurs intermentally, or intersubjectively (between people during discourse), and then through various processes these become intramental (within the self). Often the students' comments about their interaction with classmates inspired me to reflect as one of their collaborators and to intermentally learn from them and employ their ideas within my own thinking.

This descriptive, hypothesis-generating paper suggests that at least some students in one advanced university EFL class in Japan were able to grasp this social-constructivism through "tools" (activities) that allowed them to make manifest what their minds were modeling in temporarily shared social worlds (Thorne, 2000). These tools also allowed them to construct intermental moments that led them through the five movements toward critical collaborative autonomy (CCA) presented by Murphey and Jacobs (2000) and discussed and exemplified below.

The main tools used by the students were (a) shadowing (immediately repeating part or all of an interlocutor's words during a conversation), (b) summarizing (retelling the interlocutor's points to show comprehension after listening to a chunk of discourse) (see Murphey 1995, 
1999a, 2000, in press for additional reports), (c) action logging (writing a reflective account of class activities), and (d) class newsletters, consisting of student comments selected from their action logs (Murphey, 1993; Woo \& Murphey, 1999; Kindt \& Murphey, 2000). These tools made possible recursive participatory action research cycles of spoken and written communication that have been suggested to develop learners' reflection literacy (Hasan, 1996). In this paper I define tools of recursion in language acquisition as procedures that allow language and topics to reoccur frequently within a short time, giving learners more exposure to them by producing an input and output flood of target tokens within meaningful communication. Thus, shadowing, summarizing, action logging, and newsletters are tools of recursion since they allow repeated use of the same or similar language items, from simple repetition, to reformulation, to new production and novel use. Tools of recursion also involve listening, speaking, writing, and reading looped into activities repeatedly. However, these should not be seen as steps, but rather as different ways of repeatedly presenting language and ideas so that they are better understood and acquired. Micro-discursive activities deal with word and phrase level interactions with language and ideas, whereas macro-discursive activities involve reflecting about class activities and evaluating them and one's performances globally. Macro-discursive tools are therefore more metacognitive in nature.

In this paper, I first introduce the SLA course and describe the tools of recursion used in the course. Key concepts of CCA and Vygotskian sociocultural theory are then described. Next I use comments from student weekly action logs to illustrate how the movements toward CCA manifested themselves in student reflection. ${ }^{1}$ In choosing this description format, I am guided by Thorne's suggestion: "When SLA researchers attempt to 'get at what's going on' in processes of second and foreign language learning, the unit of analysis and the context within which such research takes place become crucial for the validity of the results." He further reminds us that "context, language (learning and use), and subjectivity are analytically separable, but must be understood holistically and interdependently to make sense of 'situated activity'. . . [and] context is not another variable, but rather is in part productive of, and in part produced by, collective and individual human activity" (2000, p. 263).

\section{Course Description and Structures of Invitation}

During the spring semester of 2000 I taught an advanced level university EFL course titled Second Language Acquisition. It is described as 
follows in the course handbook:

This course introduces students to the guiding questions, theory, and research methods in the field of Second Language Acquisition. The class will attempt to model the latest SLA findings in learning theory by having interactive classes that are fun. Students will be able to use their own experience as second language learners and will conduct a short research project on themselves. Students will read a good deal and discuss the material in class.

The students were third-and fourth-year Japanese university students, all about 21 years of age except for one woman in her thirties. Four male and 32 female students finished the course out of the 50 students originally enrolled. Most were English majors and had had some experience abroad. Many were planning to be teachers and six or seven were going to study abroad for a year starting the following semester. Some wanted to study with an English native-speaking teacher and were not particularly interested in SLA at the outset.

The two texts for the course were How Languages are Learned (Lightbown \& Spada, 1999) and Seven Kinds of Smart (Armstrong, 1999). How Languages are Learned surveys the field of SLA in a very accessible manner for language learners and teachers. Seven Kinds of Smart describes Howard Gardner's theory of multiple intelligences for a general non-academic audience. During the semester students also read eight articles relevant to class content.

Students began the course by writing action logs with double-entry journals citing passages from the assigned readings on the left-hand page and commenting on them on the right. In the third week of the course I introduced mind-mapping ${ }^{2}$ (Buzan, 1977), which proved to be a more constructive and interesting way for them to conceptualize the material and discuss it with their peers.

The details of the SLA course are given to situate it, while the components described below are not specific to the course. I do not wish to emphasize the class content but rather the tools which allow students to move toward CCA, whether in a content based instruction (CBI) class or in a language class. The present class entailed both kinds of focus.

\section{The Use of a Language Laboratory}

The weekly 90-minute class was held in a Sony LLC-9000 System language laboratory. The laboratory console permitted the random or 
adjacent pairing of students for recording conversations. Since students recorded a weekly average of 25 minutes of conversations with randomly chosen peers from each class for listening to and evaluating at home, the recording activity took up a third of the class time. The rest of the class was spent on other activities, including teacher-fronted lectures and discussions.

\section{Shadowing, Summarizing, Extending, and Rejoinders}

The students were initially taught shadowing and summarizing (Murphey, 1995, 1999a, 2000, in press) and later extending and rejoinders. As mentioned, shadowing is repeating parts of another's speech as a confirmation, and summarizing helps to encourage negotiation and retention. Extending refers to asking questions in order to extend conversations and get more information. Rejoinders (e.g., Wow! Really! Oh, that's too bad!) are short expressions made by the listener to give the speaker feedback and to show comprehension and empathy.

\section{Action Logs}

Action logging (Murphey 1993; Woo \& Murphey, 1999) refers to the students' written evaluation of the activities done in class and their subsequent reflection on the activities' usefulness for their learning. These comments were kept in notebooks which I read weekly to find out what the students liked and what they thought helped them to learn. I was also able to give feedback personally to individuals. By writing logs, students could review what they had done and could feel more involved in the course since they had ongoing communication with the teacher and could actually influence the course procedures.

\section{Newsletters}

I often chose student comments from their action logs to place in a short class newsletter (Murphey 1993; Woo \& Murphey, 1999; Kindt \& Murphey, 2000). These comments highlighted important issues raised by the students. Some comments were positive reports of strategy use that inspired other students. However, questions and confusions were often noted and I responded to them either in the newsletter or orally in class. Different views that showed students constructing different ideas and opinions were also included. The newsletters were passed out at the end of class and were read as homework. Students were also asked to talk to their partners about the newsletter contents and to write about what impressed them in their next action logs. Newslet- 
ters were given out eight times (weeks $5,6,7,8$ and in 10,11, 12, and 13 ) in the thirteen-week semester. This way of sharing student voices with the rest of the class took advantage of the knowledge present in the group and promoted an intermental focus on certain ideas.

\section{A Typical Class}

A typical class started off with the students finding new partners to sit with, thus adjusting to new people and receiving different influences upon their understanding of the course readings and concepts. During the first few minutes of each class, the students exchanged names and telephone numbers (so they could call for homework if needed or assigned), then read, compared, and discussed each other's action logs. Next they recorded conversations with their peers. Each conversation lasted from 5 to 10 minutes and often began with an easy topic to warm up their English discussion skills (e.g., "Tell me three things you did last weekend."). Later conversations involved questions about course content. The students usually had three to five conversations on their tape to listen to after each class.

The recordings were usually followed by a teacher-led portion of the class in which I told stories and anecdotes relevant to some idea in the course, gave short lectures on different theories and practices, or addressed ideas raised in the action logs. I did not lecture directly on the content of the class readings unless misunderstandings had been noted in the action logs. Instead the students relied mostly on each other, their recorded discussions, and mind maps for learning the material in their books. I often demonstrated the key learning tools (e.g., shadowing, summarizing, extending, rejoinders) with a student partner.

The last few minutes of each class entailed copying down the homework assignments. These usually included the readings for the following week, listening to the tapes, meeting or calling their partners and asking them questions concerning the readings, reading and commenting on newsletters and articles, and perhaps asking informants not in the class for some sort of information. Students turned in their action logs on Fridays and they were returned on Monday, in the next class.

I felt that if students could connect the SLA concepts they read about with their own language learning, they would become more self-aware. For example, recording conversations on weekend activities using shadowing, summarizing, extending, and rejoinders (SSER) was, at first glance, merely an activity to focus attention on certain conversation techniques, thereby encouraging the students to reflect in action (Schön, 1987). However, the students also reflected on their perfor- 
mances while listening to their cassettes at home by evaluating their use of the techniques. This metacognition was meant to develop their reflective literacy (Hasan, 1996). In fact Swain's recent research suggests that students learn during stimulated recall sessions (2000a), and writing an action log while listening to and reflecting on one's tape is suggested here to be one type of stimulated recall. This activity allowed the students to participate in SLA research concerning their own language learning.

\section{The Essential Concepts of CCA and Constructivism}

Recently Murphey and Jacobs (2000) proposed the concept of "critical collaborative autonomy" as a potentially fruitful way of conceptualizing student development. Whereas combining collaboration and autonomy may sound like an oxymoron, the concepts actually go hand in hand. The more that people interact and collaborate, the more choices they become aware of and the more autonomously they can act (see Vygotsky's intermental to intramental process [Wertsch, 1991]). Being autonomous was therefore not defined as acting alone, but rather as being able to take responsibility for one's learning and development (Murphey \& Jacobs, 2000). The critical component was suggested to be necessary since there is some danger in overly acquiescent and sheepish collaboration as well as in overly self-centered autonomy. Being critical is thus meant to enrich both the community and private domain with open questioning and a continual search for improvement.

Murphey and Jacobs (2000) proposed that learners tend to move through several overlapping "movements" or stages on their way to CCA: (a) socialization, (b) dawning metacognition, (c) initiating choice, and (d) expanding autonomy. Inherent in the idea of these movements are Vygotsky's concepts of the zone of proximal development (ZPD), intermentality, social-constructivism, and tools of mediation (Vygotsky, 1934/1962; Wertsch, 1991).

The ZPD refers to those things that one is not quite ready to do alone, but can do with the help of another person. For example several students in the SLA class had no previous experience with juggling and could not juggle alone but were able to do it to some degree with a partner. In this example the activity is at first located within the learners $^{s}$ ZPDs (their potential) and enacted (scaffolded) intermentallybetween two people. Only later, through further participation, does it become an intramental ability, residing within the mind of the learner. These phenomena are captured by M. C. Bateson when she writes "Participation precedes learning" (1994, p. 41; see also Lave \& Wenger, 1991). Participation opens the door to activities that involve 
intermentally constructed understandings in temporarily shared social realities (Thorne, 2000). These can lead to individual appropriation and use.

Social-constructivism is a metaphor that can be more illustrative of student and teacher learning than the widespread metaphor of transmission (see Oxford et al., 1998; van Lier, 2000). To put it simply, when teachers and students think along the lines of transmission, teachers speak and students listen. When teachers apply a metaphor of constructivism to learning (often unconsciously), they tend to scaffold (or present) appropriate experiences. This encourages their students to construct individual understanding and to share it with others in the group to further their learning. Such teachers realize that students construct their understandings in different ways and that the results are continually and dynamically developing and are rarely identical. When these constructions are shared, as in newsletters, they produce the awareness (Langer, 1989) that there is not necessarily one correct answer or way to say something, and that we are continually constructing our language, our understanding, and our lives. It then follows that collaborating with others (e.g., creating intermental spaces) enriches our ability to construct our own understanding.

Finally, in Vygotskian sociocultural theory, tools are seen to mediate the way that we perform activities (Wertsch, 1991). Just as telephones, faxes, and computers mediate how we communicate with others, the tools described in this article mediate (e.g., facilitate and change) how students socially negotiate their language learning, SLA content, their beliefs and attitudes, and their relationships with one another.

\section{Evidence of Movement}

Evidence for the development of CCA through five stages or movements (socialization, dawning metacognition, initiating choice, expanding autonomy, and CCA) discussed in Murphey and Jacobs (2000) is presented below as comments from student action logs as well as teacher classroom observations. Action $\log$ (al) numbers (1 to 13) or newsletter (nl) numbers ( 1 to 8 ) are provided to locate the comment in time. Minor corrections were made to the student comments before putting them into the newsletters but comments from action logs have not been corrected.

Of the 36 students finishing the course, about 12 students were regularly published in the newsletters, another 12 occasionally, and another 12 perhaps not at all. However as the comments appeared in the newsletters anonymously and the logs were returned to students, there is no record of the authors. The newsletters were designed to be a com- 
munal space in which the ideas expressed became topics for discussion for all. Even though some students may not have had their comments published in the newsletter, most were discussing them in their conversations and action logs and were obviously learning from their peers. However, it is possible that some students may have felt slighted when their comments were not published and this point may need teacher attention. Furthermore, since the comments came from near peer role models (Murphey, 1998) they were within most students' ZPDs and were easy for the other students to understand and identify with.

The following section presents student comments which support the suggestion (Murphey \& Jacobs, 2000) that there are five movements involved in reaching CCA.

\section{Socialization}

Socialization, the first movement toward CCA, emphasizes building rapport. This is seen as a prerequisite for learners to be able to work comfortably together. Evidence for socialization comes from student comments about getting to know each other and their feelings of solidarity with their classmates:

It was a lot of fun to juggle in the Green Area! When we made a big circle and played juggling, I felt that we are united through juggling. I was very happy. I feel a bigger happiness when many people succeed in a thing (ex. juggling) than when I succeed alone. The more people there are, the greater joy I can get. (nl-5)

The newsletters appeared to be instrumental in helping students develop a sense of community:

I enjoyed reading it [nl-8] as usual but I felt missed [sad] because this could be the last NL for me. NLs are interesting for students because it is not only the review but also like a real letter from friends. (al-13)

That socialization develops over time and supports learning was expressed well by one student in her final action log:

At first, I was very nervous, because this course was very difficult, and I couldn't understand well. But gradually, I noticed that I should ask other classmates what I couldn't understand. 
After I noticed it, I could relax very much. The mid-term exam was unusual, but it improved me very much. We could help each other [on the exam] and learned a lot of things. . . This class's system that to tell others what I understand and ask others what I could not understand is very good. (al-13)

A language laboratory with immovable consoles is not a particularly amenable environment for the development of community feelings. However, the limitations of the setting were overcome by regularly changing seat partners, varying partners for the recorded conversations, and providing socializing activities.

\section{Dawning Metacognition}

The second movement involves the development of metacognition. Many students expressed a variety of emotions on hearing their first tapes, showing that they were reflecting on their performances:

Before listening to the tape I was not sure if there would be interesting or valuable parts on it. But actually there are a lot. Taping tells me lots of valuable things about my English. (nl-1)

The students were also surprised at what they could learn from their peers. The passage below appeared in the first newsletter:

I was most impressed by my second partner [on the tape]. She shadowed almost every key word I said. For example:

Me: Well, first of all on Friday,

Her: Friday

Me: My friend and I went to Takashima-ya

Her: Takashima-ya, okay

Me: For the first time.

Her: How was it?

She shadowed the most important words in the sentences! So I could see she really understood me while I was speaking. And the other impressive thing about her was "expanding questions!" She asked me "How was it?" after I said Takashima-ya, She tried to expand the topic and it was very helpful to me to continue the conversation. And at the end of the conversation, she said "So, let me summarize" and she summarized what I said briefly!! I was really impressed. (nl-1) 
Midway through the semester, at least some students were grasping the gray areas of SLA research and were reflecting on their emotions as well:

When I read the HLL [How Languages are Learned] book, I was irritated sometimes because it did not have clear answers for each question. However, I realized that as research proceeds, questions tend to have no single or simple answer. And that is why the research is so interesting. ( $\mathrm{nl}-3)$

By the end of the semester, several students were extending metacognition beyond the classroom, thus providing evidence of generalizing learning to other contexts. In a final action $\log$ I read this insightful reflection that is contributing to my own research on shadowing:

Young children [in the kindergarten I work in once a week] always shadow. Their eyes are fixed on my lips when I speak English to them. After two or three times of exposure to the phrase or word, they start to move their lips. They are going backwards if we use your concept. They start from silent shadowing to selective and to full shadowing. Once they acquire the new phrase/word they move forward from full to selective to silent. It seems. So Shadowing must be good for learning second language. It's sad we forget how to shadow as we get older. (al-13)

It is suggested that the multiple recursive opportunities afforded by the reflective tools of taping while shadowing and summarizing, action logging, and newsletters facilitated the development of metacognition. Such tools allowed discourse and ideas to be re-observed and analyzed. As Swain (2000a) has pointed out, the act of verbalization is an act of learning and it also serves to externalize thoughts which can then be objects of further reflection. Obviously recording the students' verbalizations on tape and in action logs and newsletters provided the potential for further reflection and learning.

\section{Initiating Choice}

The first three movements towards CCA, socialization, metacognition, and initiating choice, can happen from the beginning moments in a new group. However, the teacher can structure activities so that the movements happen more intensively. Teachers can help students who 
have had little previous choice in what or how they studied to gradually consider options in the ways they learn. The students in this class were asked to choose a different seat and a different partner in each class. They also had to choose the content of their conversations, although topics were often given in the beginning (e.g., discuss three things you did last weekend). They were often asked to focus on one of the four aspects of SSER (shadowing, summarizing, extending, rejoinders) in their conversations for the day. They chose the points they wanted to highlight in their action logs and they formulated their own questions for the mid-term test. These choices were greatly expanded by the end of the semester, when they created presentations and did their own self-evaluations.

One could rightly argue that these activities were not chosen but were required by the course, that the instructor was forcing students to choose. Indeed, many students would have preferred to sit beside a friend for the whole semester. Utimately, however, this disruption of the students' passive choices and the requirement to recognize the advantages of different choices may have increased their ability to create choices in the future. That some students were creating choices by the end of the course was shown by two students' independent suggestions to change the form of the final assessment. Spurred by their suggestions, the class decided to do group presentations. This developmental sequence is also captured by the student comment below concerning action logging:

At first (and two years ago in Oral Communication) I didn't like writing Action Log. [Now I understand] by writing action log, I can do "meta-activity," or "meta-my idea. "It helps me to try to understand the purposes of activities and think of what I want to do. What I want to do, what a student wants to do, leads my interest. And I can let a teacher know my idea, interest ... . etc. Such things improve the class I attend. (nl-3)

\section{Expanding Autonomy}

The fourth movement, expanding autonomy, or taking of greater control over one's learning (termed "self-regulation" in sociocultural theory), is greatly facilitated by reflection on one's own performance. Listening to audio recordings intensifies such reflection by providing the students with performance data, as the comment below attests: 
When I listened to the tape, I noticed something so nice. It was when I talked with my partner and made a mistake. I noticed that I made a mistake and corrected it myself. Before today, I thought I always do not notice when I make a mistake, so I thought I will never correct it without listening to my conversation. But it was not true. I noticed it!! I am not sure whether I corrected myself consciously or not. However, this experience gave me confidence for not being afraid of making a mistake. I also noticed that when I made a mistake, or my partner made a mistake, we both corrected it in shadowing. And, when we heard the correction of our mistakes in shadowing, we noticed that we made a mistake and what the correction was. In this case, we could correct the mistakes very naturally. Therefore, I think it is very important to tell a correction in shadowing when we notice that our partner made a mistake. (nl-6)

It can be suggested that such metacognition leads to autonomy which may first be localized to these activities and only later generalized. Expanding autonomy can carry student learning beyond the classroom and can bridge the classroom with the students' outside lives, as the example below indicates:
A few weeks ago I had a chance to talk with Singaporeans in English. (I was helping their research work by translating their questionnaire into Japanese.) When we were talking during the break, I realized I was shadowing unconsciously. I shad- owed what they said quite often. Before I took this course, I didn't respond with shadowing. But now, shadowing became a kind of habit. I shadowed a last word of the speaker. It didn't sound strange. It was a good way to make sure that I really understood what they said. So, I think using shadowing isn't strange thing to do when you talk with native speakers. I rather encourage everyone to use shadowing when they talk to native speakers! It is a great way to respond to what the speaker said and to make the conversation smooth. (al-13)

The comment below shows the ability to experiment with learning strategies and to search for personally useful strategies as a way to expand one's control over learning. This is also an explicit account of reflection-in-action (Schön, 1987): 
The moment I watched today's video, I felt very nervous because I recalled the first time when I watched it [an excerpt for a few minutes] and I couldn't listen at all and understand at all. But I changed my mind and tried to shadow. [We saw it in three parts with discussion after each.] First I shadowed what the narrator was saying. Shadowing made me able to understand most of it. I was really surprised because I could understand! After watching, we discussed what we watched. At that time, I found that I could understand but there were a lot of parts I couldn't remember in detail. So I decided to write down [take notes] next time. Then I wrote down what I could catch and shadowed. This work was very useful when I discussed it. I could reconstruct easily. In the third part, I tried to read [the outline] while shadowing and writing my own notes. Then after watching, I asked my partner only parts I couldn't catch. This way of learning I found to be very desirable. From now on I will apply this way to as many subjects as possible. (nl-6)

That the students felt safe enough to experiment with different ways of learning, to write about them, and to share them with the group shows that they were comfortable with the group. Publishing such comments in newsletters which were read by all students perhaps inspired even more near peer role modeling (Murphey, 1998).

\section{Critical Collaborative Autonomy}

CCA may not be an end state, but rather something that we flow into periodically in our attempts to run our lives as we cyclically travel through moments of intense collaboration, retreat into solitude, reflect deeply about our practices, and drift unconsciously on automatic pilot. The key may be to regularly question ourselves, our beliefs, and what we read and hear from others. At the same time, we need to be brave enough to critically make a stand based on what we know, as in the student comments below:

One thing that makes me unsatisfied with concerning the attitude of teachers in university is that generally speaking, teachers in a university are apt to prefer to provide more new information they have not taught the students rather than give a supplementary explanation and comments on exams after the tests. It might seem to be based on false beliefs that, since "students learn what they're taught," saying the same thing 
or reflecting on exams is a waste of time. However, that is not true. Even in conventional written exams, students continue to learn. (nl-5)

In the last class the students were given a short article describing a perceived incoherence in the Japanese educational system regarding Japanese university entrance examinations (Murphey, 1999b). It was a critical piece and I was curious to see how the students would react. I should note here that in my view SLA is by its nature political and entrance examinations in Japan, due to their extreme washback effect, tend to pervert SLA processes from the top down. Such topics, to my knowledge, are practically never addressed openly in the teacher-training curriculum in Japanese universities. I contend that, by reading the article and having an attentive collaborative community to communicate with, these student voices were freed perhaps for the first time. Considering that tests of unknown validity act as gatekeepers to universities that put students on the fast track to important social positions and that high school teachers feel chained to this "exam hell," it is an especially apt topic for all SLA and teacher-training courses in Japan. Many students did indeed engage themselves in the discussion and showed deep involvement, and even anger:

Actually the entrance exams themselves are not practical, I think. I took the exam, and I studied only for it. It was no fun, and not useful. I hope the exams can be changed. (al-13)

When I was a junior high and high school student, many teachers were thinking about their students very seriously. [However] their concern was only how many students would go to good high schools or universities. (al-13)

The Japanese entrance exam system produces people who know lots of vocabulary and rules but can't communicate in English. There is a TV show that makes fun of these people. But actually it's not funny. People who are laughing at them can not speak English either. It's not time for laughing. We should change the system. (al-13)

Teachers-to-be were especially concerned about this article as they were seeing the incongruence between what they were learning in methods courses about communicative language teaching and what they were expected to do in school to prepare students for entrance exams. 
In today's situation, students and teachers get too used to accepting the status quo, even if it has contradictions. They might think nothing would be changed. But they are the one who practice and receive education. They should be responsible for their education. And movement from students and teachers do have power to change the system. (al-13)

It must be really hard, but trying to be faithful to what you believe is a very important thing, I think. (al-13)

I went to my hometown to take an interview test for "practice teaching." One teacher said, "This school never has oral communication classes." I couldn't believe that! Are they crazy!? But when I read this article, I thought I experienced the last paragraph. An ideal of the Monbusho [Ministry of Education] and actual teaching are different. Teachers should not be satisfied with their way of teaching. Teachers should think (check) students can understand well and enjoy learning. (al-13)

Obviously the students were on different time schedules in their development toward CCA. However, it is crucial for the teacher to find multi-functional tools which provide opportunities for learning at any particular moment. For example, action logging offers the chance for all students to socialize, reflect, and be critical, yet they may be used by different students in particular ways depending on their developmental trajectories. As teachers, our effectiveness may depend in part on equipping ourselves with such multi-functional tools which provide a host of doorways for students. But (to paraphrase a line from the movie Matrix) it depends on learners which doors (and in which order) they wish to open.

\section{Conclusion}

This description of exploratory teaching and participatory action research is aimed at hypothesis generation rather than testing, and the ideas presented here obviously need further research. It is suggested that the key tools described above allowed students to progress toward CCA and to form a collaborative community of interthinkers (Mercer, 2000). The micro-discursive tools of shadowing and summarizing and the reflective tools of action logging and newsletters can be used with practically any group to encourage overlapping zones of proximal development and the creation of shared intermental spaces. These tools 
allow students to manifest what their minds are modeling, scaffolding or creating overlapping intermental ZPDs, and allowing a flow between intermental and intramental processing (Lantolf, 2000; Vygotsky, 1934) 1962; Wells, 1999). As Swain (2000b), with reference to Pica (1994), states, "Through negotiation, comprehensibility is achieved as interlocutors repeat and rephrase for their conversational partners" (p. 98, my emphasis). Based on student comments, encouraging shadowing and summarizing during communicative activities would seem to ensure greater comprehensibility and jointly scaffolded ZPDs that allow for movement toward CCA. Action logging and newsletters intensify this process. With these tentative findings as support, this exploratory research can be summarized in the form of the following hypotheses:

1) The tools of recursion allow students to reveal, construct, restructure, and scaffold understanding recursively and intermentally using their own and their group's verbalizations. The tools allow students to participate more intensively in less threatening ways, and to gain quicker access to more central participation.

2) The tools of recursion can create a community intermental space of overlapping ZPDs.

3) These intermental spaces facilitate socialization, metacognition, and movement toward CCA.

It might further be hypothesized that teachers' own teaching ZPDs might be better adjusted to student ZPDs by learning what-learnersare-learning (e.g., through action logs), and by letting what-learnersare-learning become part of the subject matter of their courses (e.g., with newsletters) in order to better scaffold learning. As opposed to simply supplying input, this is very close to what van Lier (2000) refers to as supplying affordances through:

[a teacher's ability to ] ... structure the learner's activities and participation so that access is available and engagement encouraged. This brings ecological language learning in line with proposals for situated learning (and "legitimate peripheral participation') by Lave and Wenger (1991) and the guided participation, apprenticeship, and participatory appropriation described by Rogoff (1995) (p. 253).

Finally, Gee (1996) writes of "Discourses" (with a capital D) as, 
ways of behaving, interacting, valuing, thinking, believing, speaking, and often reading and writing that are accepted as instantiations of particular roles (or "types of people") by specific groups of people .... Discourses are ways of being "people like us" (p. viii).

While I was not conscious of this at the outset, I now see this SLA course as a kind of invitation to participate in, and create, several Discourses: (1) the Discourse of the critically collaborative and autonomous language learner, intensively collaborating and taking more control of the learning process; (2) the Discourse of the novice SLA researcher, appropriating some of the perspectives, knowledge, and language of the field through personal experience; (3) the Discourse of the critically aware teacher-learner who reflects on past learning experiences and who dares to question and criticize present situations and construct an image of something better. Gee (1996) further contends:

Schools ... ought to be about people reflecting on and critiquing the 'Discourse-maps' of their society, and, indeed, the wider world. Schools ought to allow students to juxtapose diverse Discourses to each other so that they can understand them at a meta-level through a more encompassing language of reflection. Schools ought to allow all students to acquire, not just learn about, Discourses that lead to effectiveness in their society, should they wish to do so. Schools ought to allow students to transform and vary their Discourse, based on larger cultural and historical understandings, to create new Discourses, and to imagine better and more socially just ways of being in the world (p. 190).

Striving to realize critical collaborative autonomy through the tools of SSER recordings, action logging, and newsletters seems to have created Discourses of potential. As professional educators, perhaps our own Discourses of potential lie within our ability to find recursive means to become aware of one another's thinking, to scaffold intermental spaces of overlapping ZPDs, and to create collaborative learning communities. 


\section{Acknowledgements}

Thanks are due to Kazuyoshi Sato, Robert Croker, Brad Deacon, George Jacobs, and the two anonymous JALT Joumal readers for very valuable interthinking with me. $I$ also received valuable intermentalization from a presentation of these ideas at the Dec 6-8,2000 Conference on Scaffolding held at the University of Tcchnology, Sydney. Thanks are especially due to my students for shat ing their insights and for teaching me, one another, and themselves through "making manifest what our minds are modeling."

After eleven years at Nanzan University, Professor Tim Murphey voluntarily resigned over differences in values concerning their entrance examinations. He has published books with Oxford University Press, Longman, Peter Lang, and MacMillan Language House, and has authored several book chapters and articles in journals, including TESOL Quarterly, Language Teaching Research, and System.

\section{Notes}

1. This article presents some tools of recursion and supports their use by consideration of student written comments, not by actual "first order" transcribed data. This would have been possible, however, especially for the micro-discursive strategies of shadowing and summarizing, through listening to the recorded tapes. Such research has been done by narrow transcriptions and the results support the idea of collaborative intermental ZPDs. For example, see the chapters by Ohta, Swain, Kramsch, and others in Lantolf, 2000.

2. Mind maps are simple web-like drawings with words, icons or pictures which represent larger ideas. The main topic is usually placed in the middle and the subtopics branch out in different directions. For a mind map of this article, I might draw a toolbox at the center of a page and have four branches extending to represent the four tools used. I might have other branches for CCA and the Discourses of potential. In turn, each of these branches might sub-branch and interconnect.

\section{References}

Allwright, D. (1991). Exploratory language teaching: A mini-course for XI ENPULI. Manuscript. Sao Paulo, Brazil.

Armstrong, T. (1999). Seven kinds of smart: Identifying and developing your multiple intelligences. New York: Plume.

Auerbach, E. (1994). Participatory action research. TESOL Quarterly, 28 (4), 693-697.

Bateson, M. C. (1994). Peripheral visions. New York: Harper Collins,

Buzan, T. (1977). Make the most of your mind. London: Pan Books. 
Gee, J. P. (1996). Social linguistics and literacies, London: Taylor \& Francis.

Hasan, R. (1996). Literacy, everyday talk and society. In R. Hasan \& G. Williams (Eds,), Literacy in society (pp. 377-424). New York: Longman.

Kindt, D., \& Murphey, T. (2000). Feedback and feedforward: Action logs and class newsletters. In D. Brooks, R. Long, \& J. Robbins (Eds.), On JALT99 Teacher Belief, Teacher Action: Connecting Research and the Classroom (pp. 85-88). Tokyo: JALT

Kramsch, C. (2000). Social discursive constructions of self in L2 learning. In J, Lantolf (Ed.), Sociocultural theory and second language learning (pp. 133153). Oxford: Oxford University Press.

Langer, E. (1989). Mindfulness, Reading, MA: Addison-Wesley.

Lantolf, J. (Ed.). (2000). Sociocultural theory and second language leaming. Oxford: Oxford University Press.

Lave, J., \& Wenger, E. (1991) Situated learning: Legitimate peripheral participation. Cambridge: Cambridge University Press.

Leibowitz, M. (2000). The work ethic and the habits of mind. In A. Costa \& B. Kallick (Eds.), Discovering and exploring habits of mind (pp. 62-78). Alexandria, VA: Association for Supervision and Curriculum Development.

Lightbown, P., \& Spada, N. (1999). How languages are leamed. Oxford: Oxford University Press.

Mercer, N. (2000). Words and minds: How we use language to think together. London: Routledge.

Murphey, T. (1993, January). Why don't teachers learn what learners learn? Taking the guesswork out with action logging. English Teaching Forum, pp. 6-10. Washington D.C.: USIS.

Murphey, T. (1995), Conversational shadowing for rapport and interactional language acquisition. In M. Ahmed, T. Fujimura, Y. Kato \& M. Leong (Eds,), Proceedings of The Gth Conference on Second Language Research in Japan (pp. 42-65). Niigata: International University of Japan.

Murphey, T. (1998). Motivating with near peer role models. In B. Visgatis (Ed.), On JALT97: Trends \& Transitions (pp. 201-205). Tokyo: JALT.

Murphey, T. (1999a, fall). Conversational shadowing and summarizing. EFL-IS Newsletter, p. 3. Alexandria, VA: TESOL.

Murphey, T. (1999b). For human dignity and aligning values with activity. The Language Teacher, 23 (10), 39, 45.

Murphey, T, (2000). Shadowing and summarizing (NFLRC video \#11). Honolulu: University of Hawai'i, Second Language Teaching \& Curriculum Center.

Murphey, T. (in press). Exploring conversational shadowing. Language Teaching Research, 5 (2).

Murphey, T., \& Jacobs, G. (2000). Encouraging critical collaborative autonomy. JALT Journal, 22 (2), 228-244. 
Ohta, A. S. (2000), Rethinking interaction in SLA: Developmentally appropriate assistance in the zone of proximal development and the acquisition of L2 grammar. In J. Lantolf (Ed.), Sociocultural theory and second language learning (pp. 51-78). Oxford: Oxford University Press.

Oxford, R., Tomlinson, S., Barcelos, A., Harrington, C., Lavine, R., Saleh, A. \& Longhini, A. (1998). Clashing metaphors abour classroom teachers: Toward a systemic typology for the language teaching field. System, 26, 3-50.

Pica, T, (1994), Research on negotiation: What does it reveal about second language learning conditions, processes and outcomes? Language Leaming, 44 (3), 493-527.

Rogoff, B. (1995). Observing sociocultural activity on three planes: Participatory appropriation, guided participation, and apprenticeship. In J. Wertsch, P. del Rio \& A. Alvarez (Eds.), Sociocultural studies of mind (pp, 139-164). Cambridge: Cambridge University Press.

Schön, D. (1987). Educating the reflective practitioner. San Francisco: JosseyBass.

Swain, M. (2000a). What happens to feedback? A paper presented at the Scaffolding Conference, University of Technology, Sydney, Dec. 6-8, 2000.

Swain, M. (2000b). The output hypothesis and beyond: Mediating acquisition through collaborative dialogue. In J. Lantolf (Ed.), Sociocultural theory and second language learning (pp. 97-114). Oxford: Oxford University Press.

Thorne, S. (2000). Second language acquisition and the truth(s) about relativity. In J. Lantolf (Ed.), Sociocultural theory and second language leaming (pp. 219-244). Oxford: Oxford University Press.

van Lier, L. (2000). From input to affordance: Social-interactive leaming from an ecological perspective. In J. Lantolf (Ed.), Sociocultural theory and second language leaming (pp, 245-259), Oxford: Oxford University Press.

Vygotsky, L. S. (1934/1962). Thought and language. Cambridge: MIT Press.

Wells, G. (1999). Dialogic inquiry: Towards a sociocultural practice and theory of education. Cambridge: Cambridge University Press.

Wertsch, J. (1991). Voices of the mind: A sociocultural approach to mediated action. Cambridge: Harvard University Press.

Woo, L., \& Murphey, T. (1999). Activating metacognition with action logs. The Language Teacher, 23 (5), 15-18.

(Received October 4, 2000, revised Dec. 30, 2000) 